\title{
The use of nile tilapia (Oreochromis niloticus) cultivation wastewater for the production of romaine lettuce (Lactuca sativa L. var. longifolia) in water recirculation system
}

\author{
Hefni Effendi ${ }^{1,4} \cdot$ Sri Wahyuningsih ${ }^{2} \cdot$ Yusli Wardiatno $^{3}$
}

Received: 22 January 2016/Accepted: 25 April 2016/Published online: 9 May 2016

(c) The Author(s) 2016. This article is published with open access at Springerlink.com

\begin{abstract}
In the recirculation aquaponic system (RAS), fish farming waste was utilized as a nutrient for plant, minimizing the water need, reducing the waste disposal into the environment, and producing the fish and plant as well. The study aimed to examine the growth of romaine lettuce (Lactuca sativa L. var. Longifolia) in aquaponic system without the addition of artificial nutrient. The nutrient relies solely on wastewater of nile tilapia (Oreochromis niloticus) cultivation circulated continuously on the aquaponic system. The results showed that tilapia weight reached $48.49 \pm 3.92 \mathrm{~g}$ of $\mathrm{T} 3$ (tilapia, romaine lettuce, and inoculated bacteria), followed by T2 (tilapia and romaine lettuce) and T1 (tilapia) of $47.80 \pm 1.97$ and $45.89 \pm 1.10 \mathrm{~g}$ after 35 days of experiment. Tilapia best performance in terms of growth and production occurred at T3 of $3.96 \pm 0.44 \mathrm{~g} /$ day, $\quad 12.10 \pm 0.63 \% /$ day, $96.11 \pm 1.44 \%$ and $1.60 \pm 0.07$ for GR, SGR, SR, and FCR, respectively. It is also indicated by better water quality characteristic in this treatment. Romaine lettuce harvests of $\mathrm{T} 2$ and $\mathrm{T} 3$ showed no significant difference, with the final weight of $61.87 \pm 5.59$ and $57.74 \pm 4.35 \mathrm{~g}$.
\end{abstract}

Hefni Effendi

hefni_effendi@yahoo.com

1 Center for Environmental Research, Bogor Agricultural University (IPB), Dramaga, Bogor 16680, Indonesia

2 Graduate Program of Aquatic Resources Management, Bogor Agricultural University (IPB), Dramaga, Bogor 16680, Indonesia

3 Department of Aquatic Resources Management, Faculty of Fisheries and Marine Sciences, Bogor Agricultural University (IPB), Dramaga, Bogor 16680, Indonesia

4 Department of Aquatic Resources Management, Faculty of Fisheries and Marine Sciences, Bogor Agricultural University (IPB), Dramaga, Bogor 16680, Indonesia
Overall, the integration of tilapia fish farming and romaine lettuce is potentially a promising aquaponic system for sustainable fish and horticulture plant production.

Keywords Aquaponic · Growth · Production - Romaine lettuce · Tilapia

\section{Introduction}

Aquaculture has been a fast-growing industry because of significant increases in demand for fish and seafood throughout the world. It is growing more rapidly than any other segment of the animal culture industry (Qin et al. 2005). The development of this activity causes extremely high water needs, regardless of water scarcity (McMurtry et al. 1997), and accompanied by increasing environmental impacts (Endut et al. 2011). On the other hand, the clean water lack and land loss led to a decline in agricultural output which is the accommodation of human population growth (Fedoroff et al. 2010).

Discharge from tank effluents in aquaculture contain dissolved nutrient such as nitrogen $(\mathrm{N})$ and phosphorus $(\mathrm{P})$, specific organic and inorganic compounds, and total suspended solids (TSS). These constituents originate primarily from uneaten feed and metabolic wastes from the fish (Seawright et al. 1998; Piedrahita 2003; Sugiura et al. 2006). These waste will be accumulated in the culture system and exerting a negative feedback on fish growth and survival (Beveridge et al. 1997). From several types of nitrogen dissolved in the water, ammonia $\left(\mathrm{NH}_{3}\right)$ is most dangerous for fish, and most of tropical species are generally more sensitive to ammonia (Effendi et al. 2015c; Wang and Leung 2015). $\mathrm{NH}_{3}$ causes decreasing growth due to reduced appetite and feed intake level (Hargreaves and 
Kucuk 2001). Ammonia in water is present in two forms, referred to as total ammonia nitrogen (TAN), and represented as non-ionized ammonia $\left(\mathrm{NH}_{3}\right)$ and ionized ammonia $\left(\mathrm{NH}_{4}{ }^{+}\right)$(Francis-Floyd et al. 1996; Losordo et al. 1998; Hargreaves and Kucuk 2001; Rahmani et al. 2004; Rijn et al. 2006; Titiresmi and Sopiah 2006).

Thus for further expansion of aquaculture activities, development and application of new technologies are required, by which water and nutrients can be recovered during cultivation process, so as to reduce the impact on environment ( $\mathrm{Hu}$ et al. 2015). Recirculation aquaponic system (RAS) is a promising technology in the integration of fish and hydroponic plant production (Endut et al. 2010). RAS is designed to replace 5-10\% of the system volume daily with new fresh water (Masser et al. 1999). Aquaponic systems are recirculating aquaculture systems that integrate hydroponic production of plants and the aquaculture production of fish in recirculation systems (Diver 2006; Tyson et al. 2011; Rakocy et al. 2006; Endut et al. 2010; Roosta and Hamidpour 2011; Zheljazkov and Horgan 2011). In this system, ammonia is converted by nitrification bacteria and assimilated by the aquaponic plants (Tokuyama et al. 2004). Compared with the conventional cultivation system, RAS is more profitable and able to provide additional benefits. Aquaponics can be used as a method or system to reduce water requirements, and fish and vegetables can be produced in a mutually benefit water-reuse (McMurtry et al. 1997; Simeonidou et al. 2012).

Plants that commonly used in aquaponic are water spinach (Endut et al. 2010, 2011; Effendi et al. 2015a), spinach (Shete et al. 2013), Lettuce (Simeonidou et al. 2012; Buzby and Lin 2014; Effendi et al. 2015b; Wahyuningsih et al. 2015), tomato (Roosta and Hamidpour 2011), cucumber (Tyson et al. 2008; Graber and Junge 2009), and pepper (Roosta and Mohsenian 2012). Vegetable such as lettuce can be used in aquaponics system, because it can be harvested in a short time (3-4 weeks in the system), and relatively fewer problems with pests compared with fruiting plants, has low to medium nutritional requirements and is well adapted to aquaponic systems (Diver 2006, Rakocy et al. 2006). The type of romaine lettuce (Lactuca sativa L. var. Longifolia) is green, and loved by consumer because its leaves are crispy (Zhan et al. 2012, 2013).

Nile tilapia (Oreochromis niloticus) is a type of fish used in the aquaponics system (Delis et al. 2015; Liang and Chien 2013; Love et al. 2015; Wang et al. 2016). Nile tilapia has a good tolerance level to various environmental conditions, well-grown in aquaponic system using vegetables (Effendi et al. 2015c), and has a high economic value (Diver 2006). Therefore, this study aimed to examine the growth performance of romaine lettuce and nile tilapia in recirculation aquaponic system without the addition of artificial nutrient, and compare it with the system without the addition of plants.

\section{Materials and methods}

The study was conducted for 6 weeks on February-April 2015, in the Laboratory of Center for Environmental Research (PPLH-IPB), Indonesia. This research used recirculation aquaponic system (RAS), where the water was not changed during the experiment. RAS consisted of nine aquariums $\left(80 \times 40 \times 40 \mathrm{~cm}^{3}\right)$ filled with $100 \mathrm{~L}$ of water for fish cultivation, tank $(60 \mathrm{~L})$ added biobal as bacteria surface media growth, and hydroponic subsystem for romaine lettuce cultivation. Each set of installation was equipped with a recirculation pump and aerator. The experiment consisted of three treatments with three replications, namely treatment without crops as a control (T1), treatment containing only romaine lettuce (T2), and treatment of romaine lettuce and inoculation with commercial bacteria (T3). The design of recirculation system can be seen in Fig. 1.

The water in the aquarium prior to usage was aerated for 1 week to dissolve oxygen in the water. Tilapia was stocked in each aquarium with the same density of 20 fishes per aquarium (average $20 \mathrm{~g}$ ), sizes ranging from 9 to $10 \mathrm{~cm}$. Fishes were acclimatized for 1 week before usage, in order to accumulate fish waste to enable the supply of nutrients for romaine lettuce. Fishes were maintained for 35 days and fed with pellet (commercial feed) as much as $3 \%$ of body weight with $40 \%$ feed protein content, three times a day (morning, noon, and afternoon). Water samples were taken every week. There was no water replacement

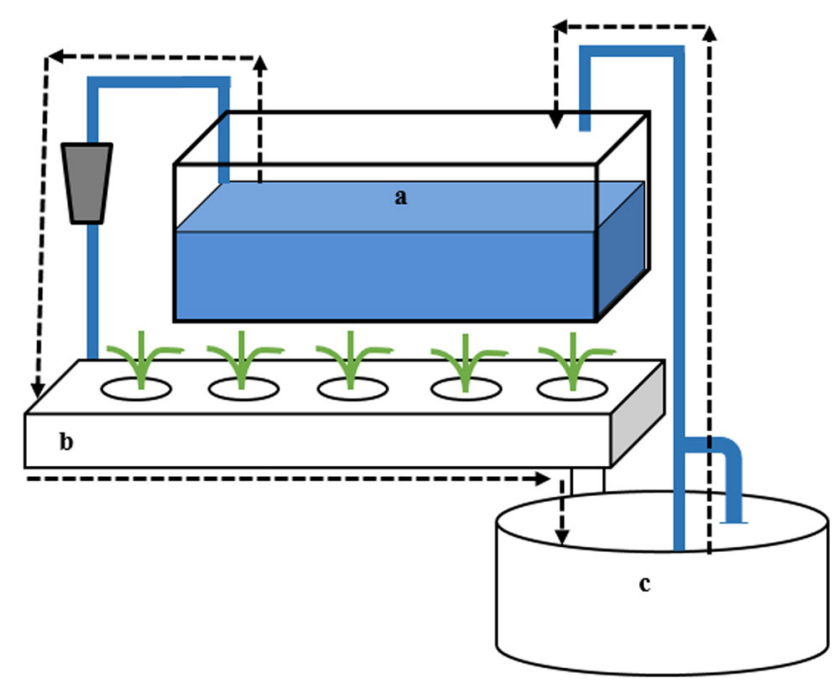

Fig. 1 Aquaponic system design. a Aquarium for fish culture; b Gutter for romaine lettuce planting, $\mathbf{c}$ Tank; dotted line with arrow water current flow 
during the experiment, except for the addition to replace the water lost due to evaporation.

Commercial bacteria (Nitrobacter $\mathrm{sp}$. and Nitrosomonas sp. with a density of $10^{6} \mathrm{CFU} / \mathrm{mL}$ ) were added to $\mathrm{T} 3$ as much as $32 \mathrm{~mL}$ per week according to the instructions on the package. The addition of the bacteria into this system is intended to supply organic substances decomposing bacteria. The addition of the bacteria was expected to increase nitrification process, expected to reduce nitrogen content, especially in the form of $\mathrm{NH}_{3}$ toxic to fish, and provided dissolved nutrients for plants.

2-week-old lettuce seedlings (average height $11 \mathrm{~cm}$ ) were planted in small pots with planting distance of $20 \mathrm{~cm}$ (except T1). Lettuce introduction into hydroponics chamber was carried out 1 week after the fish entering into the aquarium. Each experimental plot was planted five lettuces with rockwool as planting medium. Romaine lettuce was planted by the nutrient film technique (NFT) system. During lettuce cultivation, there was no addition of nutrients because the nutrients relied only from tilapia fish farming waste.

The produced biomass of nile tilapia was harvested at the end of the experiment. Meanwhile, to assess the performance of nile tilapia in the system, growth and feed data were collected. Data included the number of fed, lengths and weights of fish measured every week. $50 \%$ of fish were randomly selected to estimate the average weight, the fish production and adjustment of the amount of feed. Fish growth was monitored starting from stocking to the end of the experiment. Specific growth rate (SGR), growth rate (GR) and survival (SR) based on Zonneveld et al. (1991), and feed conversion (FCR) based on Ridha and Cruz (2001), were measured by the following equation:

$\mathrm{GR}=\frac{\left(W_{t}(g)-W_{0}(g)\right)}{t(\text { day })}$

$\mathrm{SGR}=\frac{\left(\ln W_{t}-\ln W_{0}\right)}{t(\text { day })} \times 100 \%$

where $W_{\mathrm{t}}$ and $W_{0}$ are the wet weight at time $t$ and at time 0 , and $t$ is the observation time.

$\mathrm{SR}=\frac{N_{0}-N_{t}}{N_{0}} \times 100 \%$

where $N_{0}$ and $N_{\mathrm{t}}$ are fish number at time 0 and at time t.

$\mathrm{FCR}=\frac{\text { Total weight of dry feed given }(\mathrm{g})}{\text { Total wet weight gain }(\mathrm{g})}$

Romaine lettuce growth periods, height, leaf width, and number of leaves were measured every week. The produced biomass was harvested at the end of the experiment. Lettuce daily growth rate (DGR) (Ridha and
Cruz 2001) and romaine lettuce relative growth rate (RGR) (Gaudet in Mitchell 1974) were calculated:

$\mathrm{DGR}=\frac{\left[H_{t}(\mathrm{~cm})-H_{0}(\mathrm{~cm})\right]}{t(\text { day })}$

where $H_{\mathrm{t}}$ and $H_{0}$ are romaine lettuce high at time $\mathrm{t}$ and at time 0 , and $t$ is the culture period.

$\mathrm{RGR}=\frac{\left[\ln W_{t}(g)-\ln W_{0}(g)\right]}{t(\text { day })}$

where $W_{\mathrm{t}}$ and $W_{0}$ are wet weight of lettuce at time $t$ and at time 0 , and $t$ is the culture period.

The frequency of sampling and observations was carried out every week for 35 days. Water samples were taken weekly from the tank, i.e., reservoir of water before entering into the aquarium. Water samples were analyzed for the content of TAN, nitrite $\left(\mathrm{NO}_{2}\right)$, nitrate $\left(\mathrm{NO}_{3}\right)$ and total bacteria. Dissolved oxygen and temperature were measured every week using DO meter TOA 14P, while the $\mathrm{pH}$ was measured using $\mathrm{pH}$ meter TI 9000. Water quality analysis referred to standard methods of APHA (2008).

Statistical analysis by ANOVA was carried out using statistical package for the social sciences (SPSS). If there were significant differences at significant level of 0.05 , then Duncan multiple comparison test was used to compare the means to identify significant difference between the treatments.

\section{Results and discussion}

\section{Water quality}

The quality of water at the beginning and end of the experiments is summarized in Table 1. These results were a characteristic quality of the water after treatment and before entering into the aquarium. Temperature and $\mathrm{pH}$ values fluctuated during the experiment and showed significant difference $(p<0.05)$. Water temperature for all treatments varied within a narrow range $29.37-29.80{ }^{\circ} \mathrm{C}$ at the beginning, and $28.47-29.20^{\circ} \mathrm{C}$ at the end of the experiment. The average value of the temperature during the experiment is still within the normal range (average temperature $29{ }^{\circ} \mathrm{C}$ ), but according to Colt (2006) optimal temperature for the life of tilapia is $28^{\circ} \mathrm{C}$. The $\mathrm{pH}$ values decreased during the experiment. At the beginning of the experiment, the $\mathrm{pH}$ value was still relatively high $(>7)$, then declined until the end of the experiment $(<7)$ for all treatments. The reduction in $\mathrm{pH}$ was likely caused by the respiration of fish and bacteria that produce $\mathrm{CO}_{2}$. The presence of $\mathrm{CO}_{2}$ will shift the equilibrium carbonate reaction, produces $\mathrm{H}^{+}$ions, and lowers the $\mathrm{pH}$. Decrease in 


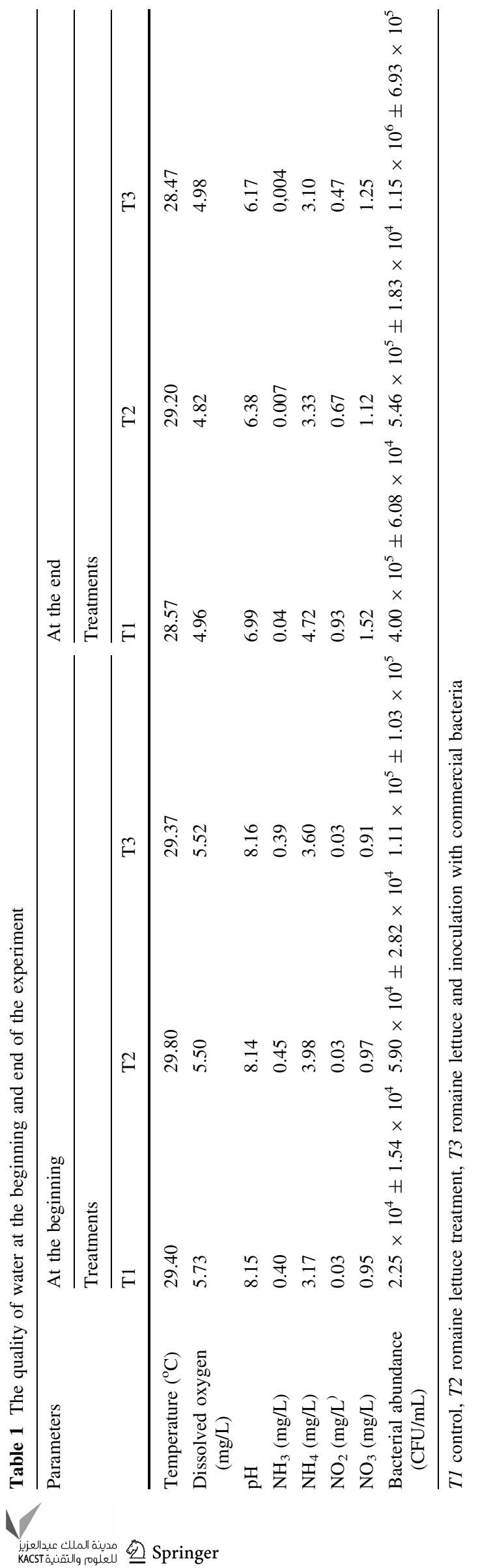

the $\mathrm{pH}$ was presumably also associated with the oxidation process undertaken by bacteria. According to Princic et al. (1998), in environments with high inputs such as ammonia from aquaculture wastewater, oxidation of this compound produces $\mathrm{CO}_{2}$ and lowers the $\mathrm{pH}$. DO levels were above $5 \mathrm{mg} / \mathrm{L}$ at the beginning of the experiment in all treatments, and ranged $4.82-4.98 \mathrm{mg} / \mathrm{L}$ at the end of the experiment. The concentration of dissolved oxygen indicated no significant difference among the treatments $(p>0.05)$. Dissolved oxygen becomes an important parameter, because it is needed in the process of oxidation of ammonia and becomes the major limiting factor for the survival of fish. The optimum DO concentration for optimum fish growth should be maintained above $5 \mathrm{mg} / \mathrm{L}$ (Masser et al. 1999; Colt 2006), and the DO concentration under $2 \mathrm{mg} / \mathrm{L}$, ammonia and nitrite oxidation by nitrifying bacteria becomes inefficient anymore (Masser et al. 1999; Hargreaves 2006).

Dissolved inorganic nutrients [ammonia $\left(\mathrm{NH}_{3}\right)$, ammonium $\left(\mathrm{NH}_{4}\right)$, nitrite $\left(\mathrm{NO}_{2}{ }^{-}\right)$, and nitrate $\left(\mathrm{NO}_{3}{ }^{-}\right)$] were not significantly different for each treatment $(p>0.05)$. But T3 provided better results when compared with T1 (control). $\mathrm{NH}_{3}$ concentration did not show any significant variation at the beginning among treatments, but showed reduction at the end of the experiment, and T3 showed value lower than $\mathrm{T} 1$ and $\mathrm{T} 2$. The concentration of $\mathrm{NH}_{3}$ for fish growth should not exceed $0.05 \mathrm{mg} / \mathrm{L}$ (Losordo et al. 1998). It indicated that the value of ammonia at the end of the experiment for all treatments is still within safe limits for fish. $\mathrm{NH}_{3}$ concentration in this study was lower than the research results of Kamal (2006), using tilapia with bell pepper (Capsicum annuum L.) in aquaponic systems reaching $0.75 \pm 0.03,0.31 \pm 0.03$, and $0.41 \pm 0.03 \mathrm{mg} / \mathrm{L}$ for treatment without plants, treatment of 15 plant per $\mathrm{m}^{2}$, and the treatment of 10 plant per $\mathrm{m}^{2}$, respectively. Different from the $\mathrm{NH}_{3}, \mathrm{NH}_{4}$ tended to increase during the experiment, and at the end of the experiment declined slightly in T2 and T3. Plants in T2 and T3 might absorb $\mathrm{NH}_{4}$ as the major source of $\mathrm{N}$ for aquatic plants. Meanwhile no plant in $\mathrm{T} 1$ caused unutilized nutrient. Therefore, the $\mathrm{NH}_{4}$ concentration in $\mathrm{T} 1$ was higher as compared with that in $\mathrm{T} 2$ and $\mathrm{T} 3$.

Nitrite $\left(\mathrm{NO}_{2}\right)$ is an unstable compound, and with enough oxygen will be easily oxidized to $\mathrm{NO}_{3}$ by nitrification bacteria. The concentration of the $\mathrm{NO}_{2}$ tended to increase during the experiment, especially in T1. Although during the experiment $\mathrm{NO}_{2}$ increased, the concentration was still safe for the life of nile tilapia. This is because oxygen supply is enough for $\mathrm{NO}_{2}$ oxidation process. Thus, $\mathrm{NO}_{2}$ did not accumulate in the system. In the circulatory system, $\mathrm{NO}_{2}$ concentration should not exceed $10 \mathrm{mg} / \mathrm{L}$ for long periods and in most cases should remain under $1 \mathrm{mg} / \mathrm{L}$ (Losordo et al. 1998). On the other hand, $\mathrm{NO}_{3}$ 
concentration also increased during the experiment, and the concentration at the end is greater than the beginning of the experiment. $\mathrm{NO}_{3}$ is the source of $\mathrm{N}$ besides $\mathrm{NH}_{4}$, and these results indicated that romaine lettuce prefers $\mathrm{NH}_{4}$ than $\mathrm{NO}_{3}$ as a source of $\mathrm{N} . \mathrm{NH}_{4}$ is a form of $\mathrm{N}$ that can be used directly by plants, while $\mathrm{NO}_{3}$ should be converted in advance into another form. According to Xu et al. (1992), in the plant tissue, accumulation of $\mathrm{NH}_{4}$ is higher than $\mathrm{NO}_{3}$, especially when grown under high $\mathrm{N}$ conditions. $\mathrm{NH}_{4}$ assimilation occurs relatively rapidly by plants and metabolic reactions are more efficient than $\mathrm{NO}_{3}$. The low $\mathrm{NO}_{3}$ removal by lettuce has been documented in other aquaponic systems (Lennard and Leonard 2006; Buzby and Lin 2014). During the experiment, the concentration of $\mathrm{NO}_{3}$ was still supportive for the life of nile tilapia. According to Watson and Hill (2006), $\mathrm{NO}_{3}$ should be maintained below $100 \mathrm{mg} / \mathrm{L}$.

Bacterial abundance in each treatment was statistically different $(p<0.05)$. The abundance of bacteria in T3 was higher than in T1 and T2, from the beginning until the end of the experiment. Addition of commercial bacteria in T3 caused increasing bacterial population. The high bacterial density in T3 did not affect the high removal of inorganic

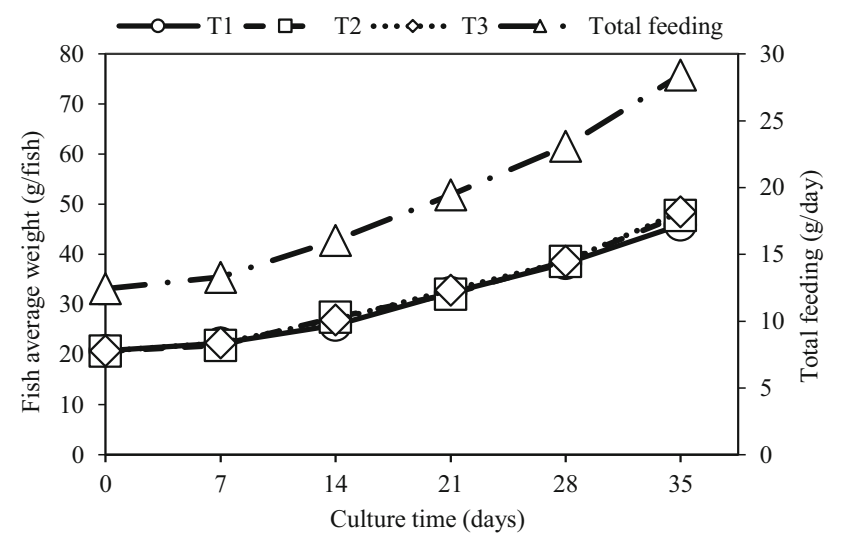

Fig. 2 Average growth in weight and feeding for T1 control, T2 romaine lettuce, T3 romaine lettuce and inoculation with bacteria nitrogen (especially $\mathrm{NH}_{3}$ ) if compared with $\mathrm{T} 1$ and $\mathrm{T} 2$. According to Tyson et al. (2008), operating optimal conditions for the biofiltration process, especially reconciling $\mathrm{pH}$ for ammonia, was more important than nitrifying bacteria population in system.

\section{Growth and feeding of tilapia}

The average weight of tilapia increased from time to time for all treatments. Final weight of $48.49 \pm 3.92 \mathrm{~g}$ maximum was reached at T3, followed by T2 (47.80 $\pm 1.97 \mathrm{~g})$ and $\mathrm{T} 1$ (45.89 $\pm 1.10 \mathrm{~g})$. Similarly, the tilapia fish biomass in the test system increased during maintenance. This could be seen from the growth of the fish biomass of $914.68 \pm 53.09 \mathrm{~g}$ (T3), followed by T2 and T1 as much as $895.51 \pm 104.23 \mathrm{~g}$ (T2) and $800.83 \pm 21.10 \mathrm{~g}$ (T1), reaching twice of the initial biomass.

Average weight of tilapia was presented in Fig. 2. T3 growth was better than that of T2 and T1. During the experiment, the fishes were fed $3 \%$ of body weight and the amount of feeding increased following the increase of fish weight each week. The average consumption of feed from the beginning to the end of the experiment ranged from $12.40 \pm 0.14$ to $29.10 \pm 2.35 \mathrm{~g} /$ day.

The GR and SGR rate in each treatment increased with time of experiment, and indicted no significant difference $(p>0.05)$. The GR and SGR of nile tilapia can be seen in Fig. 3a, b, pointing out the same trend on each treatment; however, nile tilapia in T3 showed better growth than in T1 and T2. The highest GR at the end of experiment was $3.96 \pm$ $0.44 \mathrm{~g} /$ day of T3, followed by T2 $(3.88 \pm 0.31 \mathrm{~g} /$ day $)$, and $\mathrm{T} 1(3.59 \pm 0.13 \mathrm{~g} /$ day $)$. Likewise with the highest value of T3, SGR was $12.10 \pm 0.63 \% /$ day, followed by the T2 (11.97 $\pm 0.76 \% /$ day), and T1 (11.37 $\pm 0.75 \% /$ day $)$. In the treatment without romaine lettuce and without inoculation of bacteria (T1), GR and SGR indicated the lowest value. This is in accordance with higher total ammonia $\left(\mathrm{NH}_{3}\right.$ and $\left.\mathrm{NH}_{4}\right)$ concentration in $\mathrm{T} 1$ than that in $\mathrm{T} 2$ and $\mathrm{T} 3$. Exposure of nile tilapia to relatively high concentration of total ammonia in $\mathrm{T} 1$ $\left(0.04 \mathrm{mg} / \mathrm{L}\right.$ for $\mathrm{NH}_{3} \mathrm{mg} / \mathrm{L}$ and $4.72 \mathrm{mg} / \mathrm{L}$ for $\mathrm{NH}_{4}$ at the end
Fig. 3 The rate of a GR and b SGR for T1 control, T2 romaine lettuce, $\mathrm{T} 3$ romaine lettuce and inoculation with commercial bacteria
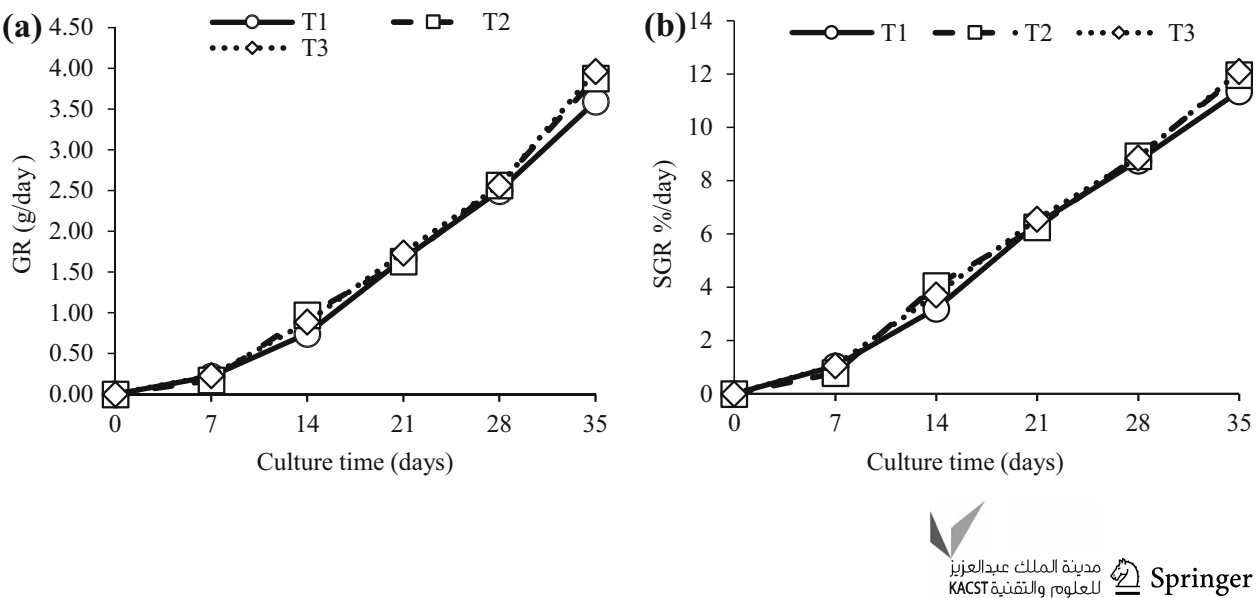
of the experiment) indicated changes in the appetite, utilization of energy, and lower growth of tilapia. Ammonia concentration with a range of $0.02-0.07 \mathrm{mg} / \mathrm{L}$ has shown to slow growth and cause several tissue damage (Losordo et al. 1998). Reduced growth caused by ammonia exposure has been documented in other researches. Increasing ammonia concentration decreased growth of all species (juvenile hybrid striped bass, channel catfish, and blue tilapia). Ammonia exposure indicated reduction of fish appetite and reduction of digestibility of consumed feed. In addition, exposure to ammonia also caused liver glycogen depletion and consequent blood acidosis. This has contributed to increased susceptibility to hypoxia, histopathology effects mainly affecting the gills and liver function (Hargreaves and Kucuk 2001).

Meanwhile, the survival rate in T3 was higher than that in $\mathrm{T} 1$ and $\mathrm{T} 2$, and the statistical difference was significant $(p<0.05)$ (Table 2). Fish death at T1 occurred in the second week until the end of the experiment, the death in $\mathrm{T} 2$ occured in the second week, fourth week, and end of the experiment, meanwhile the death in $\mathrm{T} 3$ occured in the third week until the end of the experiment. Tilapia death that occured in this study (especially in T1) was allegedly caused by exposure of ammonia during the maintenance periods. The brief exposure levels of ammonia in this study only have an impact on growth, but the ammonia will cause lethal effects when exposed for a long time. Ammonia toxicity assumed due to $\mathrm{NH}_{3}$ molecules has the ability to diffuse in the cell membrane (Colt 2006). Normally $\mathrm{NH}_{3}$ is excreted by passive diffusion across the gill epithelium, from blood to water in response to an $\mathrm{NH}_{3}$ gas partial pressure gradient maintained by combination of $\mathrm{NH}_{3}$ with protons formed from the hydration of excreted $\mathrm{CO}_{2}$ in the epithelial boundary layer. If the partial pressure of $\mathrm{NH}_{3}$ in the epithelial boundary layer is greater than that in blood, excretion of $\mathrm{NH}_{3}$ is inhibited, and $\mathrm{NH}_{3}$ will diffuse from water into the blood (Hargreaves and Kucuk 2001).

The value of food conversion ratio (FCR) showed no significant difference among treatments $(p>0.05)$. FCR is the amount of feed $(\mathrm{kg})$ which is given to produce $1 \mathrm{~kg}$ of fish meat, and the best FCR in this study belonged to T3, followed by T2 and T1 (Table 2). The lower value of FCR

Table 2 The average growth of nile tilapia (Oreochromis niloticus)

\begin{tabular}{llll}
\hline Growth indicator & \multicolumn{1}{l}{ Treatment } & \\
\cline { 2 - 4 } & T1 & T2 & T3 \\
\hline $\begin{array}{c}\text { Survival rate (SR) } \\
(\%)\end{array}$ & $89.17 \pm 0.96^{\mathrm{a}}$ & $94.44 \pm 6.45^{\mathrm{b}}$ & $96.11 \pm 1.44^{\mathrm{b}}$ \\
$\begin{array}{c}\text { Food conversion } \\
\text { ratio (FCR) }\end{array}$ & $2.02 \pm 0.13^{\mathrm{a}}$ & $1.70 \pm 0.40^{\mathrm{a}}$ & $1.60 \pm 0.07^{\mathrm{a}}$ \\
\hline
\end{tabular}

$T 1$ control, $T 2$ romaine lettuce treatment, $T 3$ romaine lettuce and inoculation with commercial bacteria. Values with the same superscript letters are not significantly different at the test level of $5 \%$ indicates less food needed to produce $1 \mathrm{~kg}$ of fish meat. FCR of T3 (1.60) means that for the production of $1 \mathrm{~kg}$ tilapia, it is required $1.60 \mathrm{~kg}$ of food. The higher ammonia concentration of $\mathrm{T} 1$ caused inefficient FCR, when compared with T2 and T3. Ammonia caused high FCR, as a result of some of the energy used to process ammonia excretion. According to Hargreaves and Kucuk (2001), high FCR in line with the increasing ammonia concentration is due to digestibility of dietary protein, and energy sources may have been affected. FCR for nile tilapia generally ranges from 1.4: 1 to 1.8: 1 (DeLong et al. 2009). The average of FCR value was comparable with the 1.69 (tilapia in the aquaponic system with prawn) and 1.72 (tilapia in the aquaponic system without prawn) reported by Sace and Fitzsimmons (2013), and better than 1.81 and 1.86 (tilapia and hydroponics bell pepper), and 2.2 (tilapia without plant) obtained by Kamal (2006).

\section{Crop yield}

Romaine lettuce (Lactuca sativa L. var. Longifolia) could grow without the addition of extra nutrients, and only comes from tilapia fish farming waste. During the experiment, romaine lettuce grew rapidly and showed a positive response to nutrients derived from tilapia fish farming waste. Romaine lettuce growth was well marked with color of fresh green leaves and no signs of nutritional deficiency (Fig. 4a). Root system grew well with the length reaching $15.5-14.5 \mathrm{~cm}$ for T2 and T3 (Fig. 4b), and there was no significant difference. During the cultivation period, there was no dead of romaine lettuce. Plants from the type of lettuce are widely used as a plant cultivated along with fish farming, because these plants are able to adapt to the nutrients from the water. There was no significant difference between $\mathrm{T} 2$ and $\mathrm{T} 3$, but $\mathrm{T} 2$ has roots longer than $\mathrm{T} 3$. The longer roots provide an opportunity to absorb more nutrients, and provide a place for attachment surface for microbial communities. These results also explain the

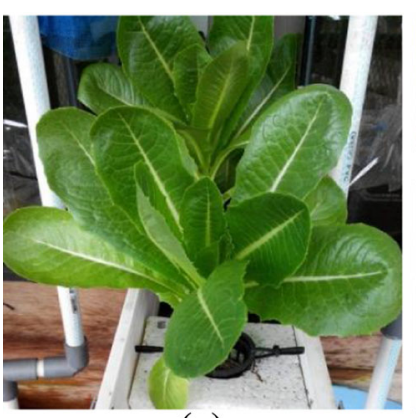

(a)

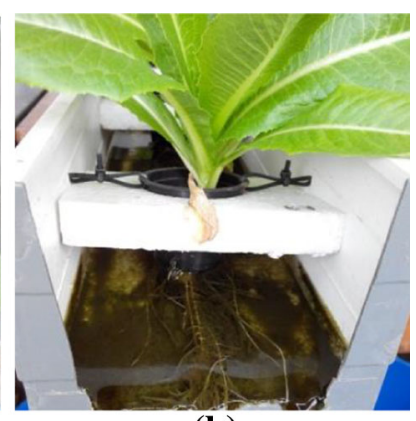

(b)
Fig. 4 The biomass of crops (a) and length of roots of romaine lettuce (b) 


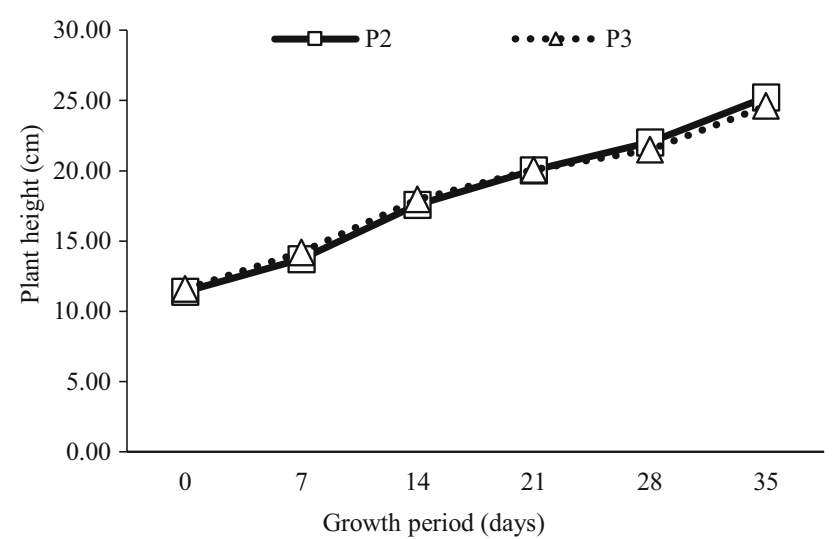

Fig. 5 The height of romaine lettuce (Lactuca sativa L. var. Longifolia)

Table 3 The growth of romaine lettuce on aquaponic systems

\begin{tabular}{lcc}
\hline Criteria & \multicolumn{2}{l}{ Treatments } \\
\cline { 2 - 3 } & $\mathrm{T} 2$ & $\mathrm{~T} 3$ \\
\hline Initial weight (g) & $18.00 \pm 0.17$ & $20.00 \pm 1.37$ \\
$\sum$ Initial leaf (strand) & $4 \pm 0$ & $4 \pm 0$ \\
Final weight (g) & $61.87 \pm 5.59$ & $57.74 \pm 4.35$ \\
$\sum$ Final leaf (strand) & $16 \pm 1$ & $16 \pm 1$ \\
DGR (cm/day) & $0.39 \pm 0.05^{\mathrm{a}}$ & $0.37 \pm 0.04^{\mathrm{a}}$ \\
RGR (g/day) & $0.035 \pm 0.002^{\mathrm{a}}$ & $0.030 \pm 0.002^{\mathrm{a}}$ \\
\hline
\end{tabular}

$\mathrm{T} 2$ romaine lettuce, $\mathrm{T} 3$ romaine lettuce and inoculation with bacteria. Values with the same superscript letters are not significantly different at the test level of $5 \%$

growth of romaine lettuce on T2 better than T3. Plant roots absorb the flowing nutrient in hydroponic subsystem, provide surface for nitrifying bacteria functioning for organic compound breakdown subsquently oxidation of ammonia to nitrate (Endut et al. 2010, 2011; Hu et al. 2015).

Results of romaine lettuce growth in terms of plant height are shown in Fig. 5. The height of romaine lettuce increased with time of experiment, and there was no significant difference. At the beginning of the experiment, plant height at $\mathrm{T} 2$ was $11.40 \mathrm{~cm}$ and at the end of the experiment reached $25.23 \mathrm{~cm}$. Meanwhile, plant height at $\mathrm{T} 3$ at the beginning of the experiment was $11.60 \mathrm{~cm}$, and reached $24.62 \mathrm{~cm}$ at the end of the experiment. The same growth pattern was shown in weight accretion of romaine lettuce. The increase of weight of romaine lettuce and other growth parameters can be seen in Table 3. The initial weight at T2 was $18.00 \mathrm{~g}$, and then the final weight was $61.87 \mathrm{~g}$. The weight of romaine lettuce at the beginning of the experiment at $\mathrm{T} 3$ was $20 \mathrm{~g}$, and at the end of the experiment reached $57.74 \mathrm{~g}$. Although the initial weight T3 is greater than $\mathrm{T} 2$, but at the end of the experiment the weight of romaine lettuce on a T3 is lower than T3. These results were likely caused by level of nutrients' absorption by the plants through the roots. Besides that the number of leaves at the beginning of the experiment was four strands either for $\mathrm{T} 2$ or $\mathrm{T} 3$, then the number of leave increased and reached 16 strands at the end of the trial for the $\mathrm{T} 2$ and $\mathrm{T} 3$.

The results of the final weight in this experiment were better than of $35.28 \pm 0.80, \quad 22.59 \pm 0.3, \quad$ and $18.32 \pm 2.43 \mathrm{~g}$ of lettuce on the media followed by gravel and the control treatments by Sikawa and Yakupitiyage (2010), and this result was lower than the aquaponic research by Sace and Fitzsimmons (2013) using the lettuce, reaching $77.5 \mathrm{~g}$ (systems with lettuce and prawns) and $78.5 \mathrm{~g}$ (system lettuce without prawns), and other aquaponic experiments using lettuce with NFT system were $107.95 \pm 2.20 \mathrm{~g}$ (Lennard and Leonard 2006).

Romaine lettuce growth in terms of DGR and RGR between T2 and T3 has no significant difference $(p>0.05)$ (Table 3). Romaine lettuce growth indicated the absorption of nutrients during the experiment. When plants are growing quickly, nutrient needs are high, and nutrient uptake will be greater (Buzby and Lin 2014). Lennard and Leonard (2006) research results also showed that lettuce grown in gravel as hydroponic media was efficient at removing nutrients. The RGR of romaine lettuce in this study (0.30-0.035) is better than the result of research by Buzby and Lin (2014), where RGR of lettuce on aquaponic system at the end of experiment only reached 0.01. Similarly, romaine lettuce growth in terms of DGR in this study is higher than result of Effendi et al. (2015b) namely $0.04 \mathrm{~cm} /$ day, and lower than the research by Endut et al. (2011) namely $1.91 \mathrm{~cm} /$ day (water spinach) and $1.32 \mathrm{~cm} /$ day (mustard green).

\section{Conclusion}

Nile Tilapia and romaine lettuce can grow well together in aquaponic system in this study. Romaine lettuce growth in T2 (nile tilapia and romaine lettuce) and T3 (nile tilapia. romaine lettuce, and addition of bacteria) was well recorded by color of fresh green leaves, and there were no signs of nutritional deficiency. Romaine lettuce could utilize nutrient originating from fish culture. This nutrient was a result of decomposition of fish excreta and uneaten food. Best growth of nile tilapia was shown by $\mathrm{T} 3$ in terms of FCR, proportional to better water quality in this treatment. Thus, romaine lettuce could, to some extent, purify water quality of fish culture media to be reused in the fish culture. Aquaponic system (nile tilapia and romaine lettuce) without water exchange can maintain the quality of the water suitable for fish and plant growth, without having to replace the water regularly like in conventional cultivation system. Further research on optimization of the number of plant 
incorporated in fish culture in aquaponic system is required.

Acknowledgments We wish to thank the Ministry of Research, Technology, and High Education of Indonesia for providing financial support through BOPTN research scheme.

Open Access This article is distributed under the terms of the Creative Commons Attribution 4.0 International License (http:// creativecommons.org/licenses/by/4.0/), which permits unrestricted use, distribution, and reproduction in any medium, provided you give appropriate credit to the original author(s) and the source, provide a link to the Creative Commons license, and indicate if changes were made.

\section{References}

American Public Health Association (APHA) (2008) Standard method for the examination of water and wastewater. Water Pollution Control Federation, Baltimore

Beveridge MCM, Philips MJ, Macintosh DJ (1997) Aquaculture and the environment: the supply of and demand for environmental goods and services by Asian aquaculture and the implications for sustainability. Aquacult Res 28:797-807

Buzby KM, Lin LS (2014) Scaling aquaponic systems: balancing plant uptake with fish output. Aquacult Eng 63:39-44. doi:10. 1016/j.aquaeng.2014.09.002

Colt J (2006) Water quality requirements for reuse systems. Aquacult Eng 34:143-156. doi:10.1016/j.aquaeng.2005.08.011

Delis PC, Effendi H, Krisanti M, Hariyadi S (2015) Treatment of aquaculture wastewater using Vetiveria zizanioides (Liliopsida, Poaceae). AACL Bioflux 8:616-625

DeLong DP, Losordo TM, Rakocy JE (2009) Tank culture of tilapia. SRAC Publication 282:1-8

Diver S (2006) Aquaponics-integration of hydroponics with aquaculture. National Center for Appropriate Technology (NCAT), Butte, pp 1-28

Effendi H, Utomo BA, Darmawangsa GM (2015a) Phytoremediation of freshwater crayfish (Cherax quadricarinatus) culture wastewater with spinach (Ipomoea aquatica) in aquaponic system. AACL Bioflux 8:421-430

Effendi H, Utomo BA, Darmawangsa GM, Hanafiah DA (2015b) Wastewater treatment of freshwater crayfish (Cherax quadricarinatus) culture with lettuce (Lactuca sativa). Int J Appl Environ Sci 10(1):409-420

Effendi H, Delis PC, Krisanti M, Hariyadi S (2015c) The performance of nile tilapia (Oreochromis niloticus) and vetiver grass (Vetiveria zizanioides) concurrently cultivated in aquaponic system. Adv Environ Biol 9(24):382-388

Endut A, Jusoh A, Ali N, Nik WBW, Hassan A (2010) A study on the optimal hydraulic loading rate and plant ratios in recirculation aquaponic system. Bioresour Technol 101:1511-1517. doi:10. 1016/j.biortech.2009.09.040

Endut A, Jusoh A, Ali N, Nik WBW (2011) Nutrient removal from aquaculture wastewater by vegetable production in aquaponic recirculation system. Desalin Water Treat 32:422-430. doi:10. 5004/dwt.2011.2761

Fedoroff NV, Battisti DS, Beachy RN, Cooper PJM, Fischhoff DA, Hodges CN, Knauf VC, Lobell D, Mazur BJ, Molden D, Reynolds MP, Ronald PC, Rosegrant MW, Sanchez PA, Vonshak A, Zhu JK (2010) Radically rethinking agriculture for the 21st century. Sci 327:833-834. doi:10.1126/science.1186834

Francis-Floyd R, Watson C, Petty D, Pourder DB (1996) Ammonia in aquatic systems. FA16. Univ. Florida, Gainesville, pp 1-28
Graber A, Junge R (2009) Aquaponic systems: nutrient recycling from fish wastewater by vegetable production. Desalin 246:147-156. doi:10.1016/j.desal.2008.03.048

Hargreaves JA (2006) Photosynthetic suspended-growth systems in aquaculture. Aquacult Eng 34:344-363. doi:10.1016/j.aquaeng. 2005.08.009

Hargreaves JA, Kucuk S (2001) Effects of diel un-ionized ammonia fluctuation on juvenile hybrid striped bass, channel catfish, and blue tilapia. Aquacult 195:163-181

Hu Z, Lee JW, Chandran K, Kim S, Brotto AC, Khanal SK (2015) Effect of plant species on nitrogen recovery in aquaponics. Bioresour Technol 188:92-98. doi:10.1016/j.biortech.2015.01. 013

Kamal SM (2006) Aquaponic production of nile tilapia (Oreochromis niloticus) and bell peppers (Capsicum annum L.) in recirculating water system. Egypt J Aquat Biol Fish 10:85-97

Lennard WA, Leonard BV (2006) A comparison of three different hydroponic sub-systems (gravel bed, floating and nutrient film technique) in an aquaponic test system. Aquacult Int 14:539-550. doi:10.1007/s10499-006-9053-2

Liang JY, Chien YH (2013) Effects of feeding frequency and photoperiod on water quality and crop production in a tilapiawater spinach raft aquaponics system. Int Biodet Biodeg. doi:10. 1016/j.ibiod.2013.03.029

Losordo TM, Masser MP, Rakocy JM (1998) Recirculating aquaculture tank production systems: an overview of critical considerations. SRAC Publication 451, USA. https://srac.tamu.edu/. Accessed 14 June 2015

Love DC, Uhl MS, Genello L (2015) Energy and water use of a smallscale raft aquaponics system in Baltimore, Maryland, United States. Aquacult Eng 68:19-27. doi:10.1016/j.aquaeng.2015.07.003

Masser MP, Rackocy J, Losordo TM (1999) Recirculating aquaculture tank production systems: management of recirculating systems. SRAC Publication 452:1-12

McMurtry MR, Cure JD, Sanders DC, Hodson RG, Haning BC, Amand PCST (1997) Efficiency of water use of an integrated fish/ vegetable co-culture system. J World Aquacult Soc 28:420-428

Mitchell DS (1974) The development of excessive populations of aquatic plants. In: Mitchell DS (ed) Aquatic vegetation and its use and control. UNESCO, Paris

Piedrahita RH (2003) Reducing the potential environmental impact of tank aquaculture effluents through intensification and recirculation. Aquacult 226:35-44. doi:10.1016/S0044-8486(03)00465-4

Princic A, Mahne I, Megusar F, Paul EA, Tiedje JM (1998) Effects of $\mathrm{pH}$ and oxygen and ammonium concentrations on the community structure of nitrifying bacteria from wastewater. Appl Environ Microbiol 64(10):3584-3590

Qin G, Liu CCK, Richman NH, Moncur JET (2005) Aquaculture wastewater treatment and reuse by wind-driven reverse osmosis membrane technology: a pilot study on Coconut Island, Hawaii. Aquacult Eng 32:365-378. doi:10.1016/j.aquaeng.2004.09.002

Rahmani AR, Mahvi AH, Mesdaghinia AR, Nasse S (2004) Investigation of ammonia removal from polluted waters by clinoptilolite zeolit. Int J Environ Sci Technol 1:125-133

Rakocy JE, Masser MP, Losordo TM (2006) Recirculating aquaculture tank production systems: aquaponics-integrating fish and plant culture (revision). SRAC Publication 454:1-16

Ridha MT, Cruz EM (2001) Effect of biofilter media on water quality and biological performance of the nile tilapia Oreochromis niloticus $\mathrm{L}$. reared in a simple recirculating system. Aquacult Eng 24:157-166

Rijn JV, Tal Y, Schreier HJ (2006) Denitrification in recirculating systems: theory and applications. Aquacult Eng 34:364-376. doi:10.1016/j.aquaeng.2005.04.004

Roosta HR, Hamidpour M (2011) Effects of foliar application of some macro and micro nutrients on tomato plants in aquaponic 
and hydropinic systems. Sci Hortic 129:396-402. doi:10.1016/j. scienta.2011.04.006

Roosta HR, Mohsenian Y (2012) Effects of foliar spray of different Fe sources on pepper (Capsicum annum L.) plants in aquaponic system. Sci Hortic 146:182-191. doi:10.1016/j.scienta.2012.08.018

Sace CF, Fitzsimmons KM (2013) Recirculating aquaponic systems using nile tilapia (Oreochromis niloticus) and freshwater prawn (Macrobrachium rosenbergii) polyculture and the productivity of selected leafy vegetables. Merit Res J Bus Manag 1:11-29

Seawright DE, Stickney RR, Walker RB (1998) Nutrient dynamics in integrated aquaculture-hydroponics systems. Aquacult 160:215-237

Shete AP, Verma AK, Tandel RS, Prakash C, Tiwari VK, Hussain T (2013) Optimization of water circulation period for the culture of goldfish with spinach in aquaponic system. J Agricult Sci $5(4): 26-30$

Sikawa DC, Yakupitiyage A (2010) The hydroponic production of lettuce (Lactuca sativa L) by using hybrid catfish (Clarias macrocephalus $\mathrm{x} C$. gariepinus) pond water: potentials and constraints. Agricult Water Manag 97:1317-1325. doi:10.1016/j. agwat.2010.03.013

Simeonidou M, Paschos I, Gouva E, Kolygas M, Perdikaris C (2012) Performance of a small-scale modular aquaponic system. AACL Bioflux 5:182-188

Sugiura SH, Marchant DD, Kelsey K, Wiggins T, Ferraris RP (2006) Effluent profile of commercially used low-phosphorus fish feeds. Environ Pollut 140:95-101. doi:10.1016/j.envpol.2005.06.020

Titiresmi Sopiah N (2006) Biofilter technology for ammonia wate treatment. J Teknol Lingkung 7:173-179 (in Indonesian)

Tokuyama T, Mine A, Kamiyama K, Yabe R, Satoh K, Matsumoto H, Takahashi R, Itonaga K (2004) Nitrosomonas communis strain YNSRA, an ammonia-oxidizing bacterium, isolated from the reed rhizoplane in an aquaponics plant. J Biosci Bioeng 98(4):309-312

Tyson RV, Simonne EH, Treadwell DD (2008) Reconciling pH for ammonia biofiltration and cucumber yield in a recirculating aquaponic system with perlite biofilters. Hort Sci 43:719-724
Tyson RV, Treadwell DD, Simonne EH (2011) Opportunities and challenges to sustainability in aquaponic systems (reviews). Hort Technol 21:6-13

Wahyuningsih S, Effendi H, Wardiatno Y (2015) Nitrogen removal of aquaculture wastewater in aquaponic recirculation system. AACL Bioflux 8:491-499

Wang Z, Leung KMY (2015) Effects of unionised ammonia on tropical freshwater organisms: implications on temperate-totropic extrapolation and water quality guidelines. Environ Pollut 205:240-249. doi:10.1016/j.envpol.2015.05.045

Wang CY, Chang CY, Chien YH, Lai HT (2016) The performance of coupling membrane filtration in recirculating aquaponic system for tilapia culture. Int Biodet Biodeg 107:21-30. doi:10.1016/j. ibiod.2015.10.016

Watson CA, Hill JE (2006) Design criteria for recirculating, marine ornamental production systems. Aquacult Eng 34:157-162. doi:10.1016/j.aquaeng.2005.07.002

Xu QF, Tsai CL, Tsai CY (1992) Interaction of potassium with the form and amount of nitrogen nutrition on growth and nitrogen uptake of maize. J Plant Nutr 15(1):23-33

Zhan L, Hu J, Pang L, Fan H (2012) Browning inhibition and quality preservation of fresh-cut romaine lettuce exposed to high intensity light. Innov Food Sci Emerg Technol 14:70-76. doi:10.1016/j.ifset.2012.02.004

Zhan L, Hu J, Ai Z, Pang L, Li Y, Zhu M (2013) Light exposure during storage preserving soluble sugar and L-ascorbic acid content of minimally processed romaine lettuce (Lactuca sativa L.var. longifolia). Food Chem 136:273-278. doi:10.1016/j. foodchem.2012.07.123

Zheljazkov VD, Horgan TE (2011) Study on shrimp waste water and vermicompost as a nutrient source for bell peppers. Hort Sci 46:1493-1496

Zheljazkov VD, Zonneveld A, Huisman EA (1991) The principles of aquaculture. PT. Gramedia Pustaka, Jakarta (in Indonesian) 